Athens Journal of History - Volume 7, Issue 4, October 2021 - Pages 319-336

\title{
Hellanicus as Peripheral and a Critic of Athens? Notes on a Study of a Fragmentary Historian
}

\author{
By Matheus Vargas de Souza*
}

\begin{abstract}
This paper explores the possibility of imagine Hellanicus of Lesbos as a politically critical author. Many works suggest that Hellanicus was a partisan of Athens or at least a sympathizer of that polis. However new approaches have proposed that authors like Herodotus criticized the external politics of Athens, even in subtle ways. Therefore this paper argues the possibilities of thinking on Hellanicus as a peripheral critic of Athenian politics and on the limitations the fragmentary condition of the texts imposes.
\end{abstract}

\section{Introduction}

Recently the debates on the political alignment of Herodotus have regained strength through some works that questioned the relations between the Histories and the political actions of the Athenian hegemony. One of the most recent works about this theme argued, like others, that Herodotus uses his narrative constructions of the past to create images that could reflect his contemporary context for the audience. ${ }^{1}$ However, most importantly, the associations between past and present were completely free, which gave Herodotus the opportunity to stay in a very comfortable position. Safe from the implications of a rigid political alignment declaration, Herodotus did not stop presenting his modest and continuous detractions, while presented the past as a mirror of the different facets of Athenian tragedy; at least in the final version of his logoi, when these were connected and revised. ${ }^{2} \mathrm{It}^{\prime} \mathrm{s}$ important to say that this argumentation explored the text of the Histories profoundly and it depended on the access of most of the nine books. Without reading big excerpts of the books, everything would be mere assumptions.

These kinds of argumentation bring us some questions about the possibilities of understanding (or at least questioning) the political alignment of different

"PhD Researcher, Federal University of Rio de Janeiro State (UNIRIO), under the supervision of Prof. Dr. Juliana Bastos Marques, Brazil.

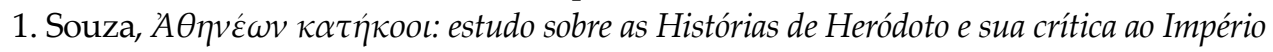
Ateniense, Masters Dissertation (Rio de Janeiro: Programa de Pós-Graduação em História Universidade Federal do Estado do Rio de Janeiro, 2020). For other recent works related to this topic, see Irwin, 2007, 2009, 2018; Munson, 2012. There is a vast bibliography about Herodotus' critical stance toward Athens. For one of the most relevant, see Souza, 2020, 30-59. The title of this paper is directly related to one of the chapters of his work, entitled 'Heródoto periférico e crítico de Atenas' (Peripheral Herodotus and critic of Athens).

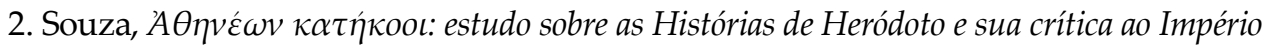
Ateniense, 2020, 155, 157, 185-186, 194. 
authors from Antiquity. There are many works about this subject, about Thucydides or some tragedy and comedy writers, for instance. Nevertheless, there is an uncountable number of authors that haven't reached us and probably never will. From some of them, we have a restricted number of fragments and these are the only material we use to (try to) understand their production and their political inclinations. In this paper, I will discuss some ways to understand one of those authors who rest in a fragmentary condition. Exploring the profound fragilities of conjecturing anything about these authors, I will suggest that an analysis like the one made on Herodotus, completely impossible to do on Hellanicus, is the only way to understand the political alignment of an author who didn't expressly write it.

\section{Interpreting Hellanicus}

Hellanicus of Mytilene has been traditionally crowned as the father of horography in Ancient Greece. This interpretation commonly comes together with the whole theory about the development of Greek historiography created by Felix Jacoby. A theory that was full of a linear development idea, in an evolutionist meaning, by the way. In this theory, it's important to note, Thucydides is the ideal telos of the Greek historiography, and all the other authors are evaluated by this criterion. ${ }^{3}$ In fact, the hegemony of Thucydides in historiographic theories at Jacoby's time is a kind of second-wave, since the $19^{\text {th }}$ century, that elected Thucydides as the masterpiece of Greek historiography, culminating in the model of Jacoby, based on Ancient arguments such as Dionysius' and Cicero's. ${ }^{4}$ However, Jacoby became the most important reference to the fragments' studies of Greek historians, especially because of his prolific opera. Joseph Skinner, in a recent paper, has remembered the relevance of Jacoby, despite the recent criticism on imprecisions of Jacoby's work. ${ }^{5}$ It is impossible to declare something about Hellanicus' fragments, for example, without talking about Jacoby's theories. Furthermore, it is impossible not to criticize it nowadays.

3. Marques, "Historicizando as categorias de Felix Jacoby: os gêneros historiográficos da Antiguidade e sua classificação pelos modernos," in Fronteiras Mediterrânicas (Porto Alegre: Editora Fi, 2019), 230, 234-237.

4. Payen, "A constituição da história como ciência no século XIX e seus modelos antigos: fim de uma ilusão ou futuro de uma herança?" História da Historiografia, no. 6 (2011): 120-121; Marques, "Historicizando as categorias de Felix Jacoby: os gêneros historiográficos da Antiguidade e sua classificação pelos modernos," 2019, 235-236; Skinner, "Writing Culture: historiography, hybridity, and the shaping of collective memory," in Histos Supplement 11 - Shaping Memory in Ancient Greece: Poetry, Historiography, and Epigraphy (2020), 199.

5. Skinner, "Writing Culture: historiography, hybridity, and the shaping of collective memory," 2020, 198. 
One of the relevant points Jacoby has imposed on the studies of Hellanicus is a claimed inspiration of Herodotus upon the birth of horography, as a kind of inspiration for local and patriotic narratives. ${ }^{6}$ It is interesting to see that a contrary possibility had been thought by B. Perrin, some years before Jacoby. There was indeed much freedom in these interpretations: before Jacoby, Perrin was saying that many titles of Hellanicus' works were in fact subtitles of an entire opera. ${ }^{7}$ Jacoby, of course, tried to crystalize a chronology that made his theory plausible and placed Hellanicus as a kind of minor successor of Herodotus. In his mind, there was a clear evolutive chronology between Hecataeus and Thucydides, where Herodotus was a kind of an intermediary author and where Hellanicus and others were different forms of evolution in the rational Greek historiography, nothing but different and insufficient if compared with Thucydides. ${ }^{8}$ This is probably the first point we could contradict in Jacoby's vision of Hellanicus. In fact, recent studies have pointed out a significant possibility that Herodotus would have lived until after the 420s BC, probably seeing the end of the Peloponnesian War in 404 BC. ${ }^{9}$ If these propositions are correct, it makes Herodotus' production date of the Histories later than the production of Hellanicus' work, which is 407 BC. I will point this out later in this paper, but, for now, it must be clear that there is a possibility that Jacoby's statements are partially wrong. And I say 'partially' because it is not impossible that Herodotus has inspired some of Hellanicus' writings, but what needs to be considered now is that the opposite direction of influence could have happened as well.

Some of Jacoby's notes have been questioned in the last decades and one of the most recent and relevant responses to the German philologist is the one delivered by John Marincola. Defending the necessity of a new taxonomy for the different kinds of ancient historians, Marincola is one of those who asked for a less teleological comprehension of the Greek historiography development, as well as a less rigid categorization.

[...] enquanto Jacoby parte de uma pergunta a priori, de caráter evolutivo, Marincola faz o contrário, pois seu propósito é entender a lógica interna da narrativa do autor em primeiro lugar para só depois (talvez) interpretá-lo dentro do conjunto. ${ }^{10}$

6. Marques, "Historicizando as categorias de Felix Jacoby: os gêneros historiográficos da Antiguidade e sua classificação pelos modernos," 2019, 238.

7. Perrin, "The Iereiai of Hellanicus and the Burning of the Argive Heraeum," The American Journal of Philology 22, no. 1 (1901): 40.

8. Nevertheless, Perrin's considerations over Hellanicus had indeed an evolutionist sense, in the traditional primacy of Thucydides. See note 4.

9. Irwin, "The End of the Histories and the End of the Atheno-Peloponnesian Wars,"

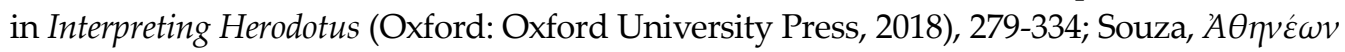
кат үंкool: estudo sobre as Histórias de Heródoto e sua crítica ao Império Ateniense, 2020.

10. Marques, "Historicizando as categorias de Felix Jacoby: os gêneros historiográficos da Antiguidade e sua classificação pelos modernos," 2019, 244. “[...] while Jacoby starts 
There is a problem, however, with no clear answer. The different criteria proposed by Marincola have a literary sense. To inquire if the text has a narrative or non-narrative aspect, for example. Even if we discover if the text is more or less synchronic, or diachronic, or if it is a kind of ethnography, or horography, even if we find out what is the relation between the text and time, generations, or understand the way how the text presents the facts in time, there is no clear way to look for a political alignment in the text. I agree with the propositions of Marincola, but what I mean is that these propositions are insufficient if we want to find concrete relations between the historiography and the political events of its own time. Unfortunately, and we shall see this further in this paper, the studies on the fragmentary Greek historians are completely arrested in a limited study of its categories, development, and meaning for Philosophy of History. It seems that all those authors are condemned to serve only thoughts about the origins of History, without any clear understanding of the political actions of writing those different histories in different times and places across Ancient Greece. I insist: the act of thinking about the origins of History and the many historiographic possibilities that have been produced in different cultural contexts is self-justified. That is not my point of disagreement. However, this aspect isn't either relevant to me when I'm looking for the possibilities of thinking about the political implications of some of those many historical writings. Finally, I believe that there is an enormous field insufficiently explored to discuss what were the political implications of those historical writings in those poleis.

There are, of course, some works that followed this path and I will approach those who thought about Hellanicus later in this paper. But for now, we need to remember the notes of $\mathrm{P}$. A. Brunt upon the studies on fragmentary authors of Antiquity. In his words:

[...] scholars have often been too precipitate in characterizing and evaluating lost histories on the basis of evidence that is irremediably insufficient, and that in particular too little account is commonly taken of the relevant characteristics of the authors who preserve the "reliquiae", their reliability in quoting or summarizing, and their own interests and purposes. What follows is necessarily a mere sketch with a few illustrations of some habits of ancient writers in quoting, paraphrasing, or epitomizing earlier works, to which in my judgement too little attention is often given. The style of a lost author can hardly be inferred from an epitome. ${ }^{11}$

with a question a priori, of an evolutive aspect, Marincola does the opposite, because his purpose is to understand first the internal logic of the author's narrative and later (maybe) to interpret it on the whole."

11. Brunt, "On Historical Fragments and Epitomes," The Classical Quarterly 30, no. 2 (1980): 477-478. 
He suggested that the idea of 'reliquiae' would be a better concept rather than 'fragments' because of the many imprecisions inherent to the many references of some authors to others that we can't read because they are lost.

'Fragments' and epitomes reflect the interests of the authors who cite or summarize lost works as much as or more than the characteristics of the works concerned. Our best evidence for the scope and content such a work does indeed consist in summaries, especially if they are relatively full and give indications of the distribution of the material in books. Only long excerpts reveal something of an author's quality, and then we need to be assured that they are representative. The most detailed narratives of secondary writers, whose credibility is no more than that of the authority or authorities they followed, also deserve the most respect [...] they are likely to be the most accurate reproductions of lost works, whereas brief notices in other works which seemingly contradict them may themselves be inexact or misleading reports by a careless epitomator. ${ }^{12}$

One of the most important points of Brunt is that we can't comprehend much of any work if we don't read a considerable amount of its material. For him, to know a text by its fragments is contradictory and he pays attention to one of the great questions about the fragmentary corpora of the Greek historians, which is the question of their style. He argues that is impossible to understand clearly the style of an old writer if we don't have access to a great part of his work..$^{13}$ And that explains the priority given by Brunt for the reading of bigger excerpts, practice with which I agree. I suggest that more than the style, we stay unable to understand clearly the political filiations of the text. And I say it because any historiographical text has a political alignment and a political impact, as it manipulates the foundations of a collective identity through the uses of collective memory and characters of the past with their meanings and actions. The recent propositions of Joseph Skinner show us that historiography had fundamental relevance to the sedimentation of a collective identity in Ancient Greece. ${ }^{14}$ But even with the Skinner's claiming for a new understanding of those fragmentary historians, and for a more cautious reading of those fragments, I believe that Brunt's observations are not at all obsolete. Even with the proposition of Skinner and with a new breath of the studies of the fragments, we have to accept the many insurmountable limitations of those studies. Not only for the apprehension of the author's style but also the political implications of the text.

In the specific case of Hellanicus, it is relevant to note that some questions are recurrent as, for example, if he did write a chronicle of Athens among his many different texts. Perrin presumed that, besides writing a chronicle, Hellanicus was

12. Idem, 494.

13. Idem, $477,480,484-485$.

14. Skinner, "Writing Culture: historiography, hybridity, and the shaping of collective memory," 2020, 189-192, 223-224. 
joining other Greeks to build a 'national' conscience. For him, Hellanicus had composed one of many "national Hellenic chronicles."15 More than a hundred years after the suppositions of Perrin and after the critics of a modern sense of nationality imposed on the Ancient Greeks, the propositions of Skinner bring that spirit back to memory. But instead of imagining a sense of crystalized nationality among the Greeks, now we know that the possibilities are more limited and that the precision in the understanding of the Antiquity requires a moderate perspective that includes the absence of generalizations and some precautions in the use of concepts and anachronisms. ${ }^{16}$ Skinner limits his work hoping to find a subtle sense of belonging that passes through the ancient texts in a crescent sense of "difference yet connectedness." 17

But Perrin's ideas are no longer sufficient either to the question of the literary gender. While Perrin considered Hellanicus' Atthis as a chronicle, Joyce presented solid arguments for a rupture in his interpretation. Criticizing broadly Jacoby's premisses, Joyce demonstrated that we have no sufficient reason to believe that Hellanicus' Atthis could be considered a chronicle, in terms of a text fully based on a chronological organization of matters. In his words, "by supposing Hellanikos to be a chronicler of any description, we create many more theoretical problems than we solve and make a nonsense of Thucydides' assessment of the Attic History and of his response to it." ${ }^{18}$ Everything showed to be a distortion caused by the rigid categories and evolutive perception of Jacoby. So it is relevant to understand that Hellanicus was not necessarily writing a specific kind of historiographical text imagined by the moderns, which makes us more distant from its real frame. However, I believe that those two works, Perrin's and Joyce's, have one specific problem that is not to consider one of the author's central characteristics: Hellanicus, like many other historians, wrote about places he wasn't from. His Atthis is just one of his works, of course, but for my purpose here, I will give more attention to it. And it is a fact that no sufficient attention has been given to the peripheral or at least outsider condition of the author. Fomenting an idea of Hellenic identity or even nationality - and that is a completely rightful point to be explored -, scholars have forgotten to inquire about the political disputes and the distance between different Hellenic communities. As Skinner pointed out:

15. Perrin, "The Iereiai of Hellanicus and the Burning of the Argive Heraeum," 1901, 43.

16. I chose to include the idea of anachronism based on the propositions of the recent book of Carol Atack, Tim Rood, and Tom Phillips, which claims for controlled use of the anachronism as a way of studying and understanding the Antiquity. See Rood, Atack \& Phillips. Anachronism and Antiquity (London: Bloomsbury Academic, 2020).

17. Skinner, "Writing Culture: historiography, hybridity, and the shaping of collective memory," 2020, 209.

18. Joyce, “Was Hellanikos the first chronicler of Athens?" Histos 3, no. 1 (1999): 16. 
Whereas the nature and significance of local history has attracted considerable comment, the distinction between local history and ethnography has gone largely unquestioned in subsequent scholarship debating the origins of the local histories of Athens and horography more broadly. ${ }^{19}$

Therefore, many studies of those (so-called) local histories didn't consider the fact that even writing about a Hellenic community, the writer is commonly writing about a strange community. Furthermore, the distinction between ethnography and horography has been based on a supposed distinction between the local history focused on the odd, and the local history focused on the equal or maybe similar. But we do not necessarily have sufficient records to know if the ancients thought like that. Even with concepts like 'barbarian', the texts mention different kinds of Hellenic people, and this hue must be remarked. Hellanicus, by no means, would write about the Athenians like the Athenians themselves. And this is a good reason by itself for us to see Hellanicus differently from other athidographers.

Some works considered these perceptions on the distance between Hellanicus and his object of writing. Charles Fornara, for example, in a cautious and restrained paper, indicates that Hellanicus probably narrates one of his stories in disagreement with a current version among the Athenians. Even considering that it would be imprecise to talk about an official version of History imposed by the Athenian state, Fornara comments that the disagreement itself should be more interpreted once it could have political implications in Hellanicus' rhetoric. ${ }^{20}$ However, Fornara didn't explore enough his own argumentation when he explains the political implications of a different version of the history of Alcmaeonid tyrannicides in Hellanicus' narrative.

19. Skinner, "Writing Culture: historiography, hybridity, and the shaping of collective memory," 2020, 201. There are other propositions of Skinner that we can't ignore, for example, his notes on the mythological question: "Attempting to divide these fragments into prose genres considered either rational or 'scientific' (i.e., geography or ethnography) or 'mythological' (mythography) is unlikely to produce anything other than a false dichotomy since distinguishing between mythic and historical pasts appears to have been little more than a rhetorical strategy for early writers." Skinner, "Writing Culture: historiography, hybridity, and the shaping of collective memory," 2020, 217-218.

20. Fornara, "Hellanicus and an Alcmaeonid Tradition," Historia: Zeitschrift für Alte Geschichte 17, no. 3 (1968): 382-383. 


\section{Recent Approaches}

Most recently, Gabriella Vanotti has remembered that the debate on the political relations of Hellanicus with Athens became continuous since the 1970s. ${ }^{21}$ Names such as János Harmatta, Antonio Aloni, and Anna M. Biraschi defended that Hellanicus constituted himself as an opponent of Athenian imperialism. ${ }^{22}$ On the other hand, Dino Ambaglio and Roberto Sammartano argued that the political alignment of Hellanicus was with Athens and its external politics. ${ }^{23}$ Ambaglio, it is important to say, even maintaining his defense of Hellanicus as an Athenian partisan, applied to his arguments the perception that Hellanicus probably needed to be fairly cautious in his writings, in a position kind of "acrobatic." 24 In other words, a man from Lesbos (in the time we suppose Hellanicus was writing his Atthis) should be careful with his own words when talking about Athens, speaking to the Lesbians and to the Athenians as well. That is a good point in any case, but the general question stays under debate.

The recent thesis of Théodossios Polychronis is a witness to that. In a monumental work of reinterpreting and retranslating the fragments of Hellanicus, ${ }^{25}$ the question of the political alignment of the author didn't go

21. Vanotti, "Egesta ed Esione da Ellanico di Lesbo a Dionisio di Alicarnasso," in Tra panellenismo e tradizioni locali: Nuovi contribute (Messina: Dipartimento di Scienze dell' Antichità, 2011), 341, n. 75.

22. Harmatta, "La tendance politique d'Hellanicos dans les Troikà," 1975; Aloni, Tradizioni arcaiche della Troade e composizione dell'iliade (Milan, 1986), 59-62; Biraschi, Tradizioni epiche e storiografia: Studi su Erodoto e Tucidide (Naples: Edizioni Scientifiche Italiane, 1989), 41-42.

23. Ambaglio, "L'opera storiografica di Ellanico di Lesbo," Ricerche de Storiografia Antica 2 (1980): 52-53; Sammartano, Origines Gentium Siciliae: Ellanico, Antioco, Tucidide (Roma: Gustavo Bretschneider, 1998), 111-119.

24. Ambaglio, "Ellanico, un Lokalpatriotismus problematico," in Eoli ed Eolide tra Madrepatria e Colonie (Naples: Luciano Editore, 2005), 135-144.

25. Polychronis' thesis offered a solid study of Hellanicus' production and the main questions of the beginnings of historiography in Greece itself. Good examples can be found where he admonishes us to think about the choices made by the ancients, selecting what was good and bad in historiography with no verifiable criteria today (p. 8). The same happens when he points out that the scientificist criteria of the 19th century and Jacoby's teleological theory aren't useful to interpret those fragments, following authors like Marincola in the perception that the texts show us just individual perceptions of the past and present (p. 10-12). One of the most interesting things I would like to recall is that Polychronis is absolutely cautious when he ponders that the text has been deformed through the centuries in the many quotations and paraphrases, and from this perspective, the fragments are never neutral, bearing diverse meanings related to the author who quotes, and to his own points. In Polychronis' words: "[...] la thématique de l'œuvre $d u$ citateur conduit nécessairement à privilégier un type de citation, et l'agencement même des fragments constitue en lui-même une mise en perspective, une interprétation de l'original, qui n'est 
unnoticed. Unfortunately, at this specific point, he wasn't so precise as in the rest of his work. He presumed that Hellanicus wouldn't take the risk of writing many critics about Athens while his foreigner condition could put him in an uncomfortable position. ${ }^{26}$ His arguments are limited to imagining that Hellanicus was trying to crown his own literary production when he creates a rich account of Attic local traditions. ${ }^{27} \mathrm{He}$ dismisses the supposition that Hellanicus' Atthis could have been commissioned by Pericles (considering it an unnecessary hypothesis), and he is as much cautious when he doesn't defend that Hellanicus was working directly for Athens, because we don't have enough evidence of that, and because it seems to complicate the facts. ${ }^{28}$ If on the one hand, he is careful, on the other hand, he is careless, when he suggests that Hellanicus' Atthis is just a literary project thought to be enjoyable and successful. He is even more careless when he suggests that the simple fact of composing an Atthis as the last work would indicate such a project. We have no sufficient information to presume that. And most of all, we have no sufficient information to understand the rhetoric within Hellanicus' discourse. By making this supposition, Polychronis, unfortunately,

pas celle de l'auteur cité. Cela a, évidemment, des conséquences très importantes pour la compréhension d'un auteur fragmentaire; les fragments nous offrent non pas une image de l'auteur, mais, déjà, une première interprétation de ce dernier qui, par la force des choses, est multiple vu la pluralité de citateurs. [...] Fut-elle immédiatement rédigée et mise par écrit, puis copiée et publiée sous

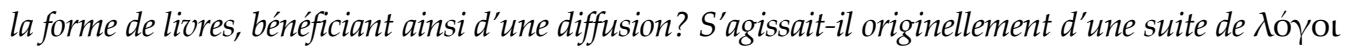

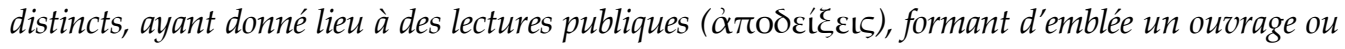
ayant été rassemblés en un tout cohérent et définitivement fixé par une rédaction écrite? Le grand nombre de titres serait-il dî̀ à une division trouvant son origine dans la transmission matérielle de l'œuvre, qui l'aurait, très tôt, livrée à la postérité sous une forme, qui, dès l'origine, ne représentait plus la vision originelle d'Hellanicos? Ces questions, faute d'éléments pertinents et certains, doivent nécessairement rester sans réponse.»

"[...] the theme of the work of the one who does quotations necessarily leads to favoring a type of quotation, and the very arrangement of the fragments constitutes in itself a perspective, an interpretation of the original, which is not the one of the quoted author. This obviously has very important consequences for the understanding of a fragmentary author; the fragments do not offer us an image of the author, but yet a first interpretation of the latter which, by necessity, is multiple, given the plurality of citators. [...] Was it immediately put into writing, then copied and published in the form of books, thus benefiting from a diffusion? Was it originally a series of distinct $\lambda$ ó $\gamma \mathrm{ol}$, having given space to public readings ( $\dot{\alpha} \pi 0 \delta \varepsilon i \xi \xi \iota \zeta)$, immediately forming a work or having been assembled into a coherent whole and definitively set by a written essay? The large number of titles, would it be due to a division having its origin in the material transmission of the work, which would have, very early, delivered it into posterity in a form that, since its origins, no longer represented the original vision of Hellanicus? These questions, in the lack of relevant and certain elements, must necessarily remain unanswered" (p. 50-51).

26. Polychronis, Hellanicos de Lesbos: Histoire des origines, origines de l'Histoire, Doctoral Thesis (Paris: Université d'Aix-Marseille - Faculté des Lettres, 2018), 113.

27. Idem, 108-109.

28. Idem, ibidem. 
did not consider the possibility that Hellanicus could write a book that included ironical, or subtle, and allusive critics using the past to speak of the present, as Herodotus has done. It is a possibility that we have to take into account. Polychronis didn't forget to say that Atthis would probably have a connection to the present, tracing parallels between the past and the present besides just narrating the old local traditions. ${ }^{29}$ However, he did not consider the possibly distant and unsympathetic position of Hellanicus.

This position was taken into consideration by Laurence Baurain-Rebillard two years before. She noticed that Plutarch witnessed how Hellanicus was the first to write that Helen had been kidnapped by Theseus, building a disgusting image of the Athenian king, who might be fifty years old, against the seven-yearold girl. ${ }^{30}$ Moreover, she pointed out a problematic question: if the text of Atthis was sympathetic to Athens, why would Hellanicus build an offensive image of Theseus? We have to remember that Theseus was an important hero to the Athenian identity and even to the imperial discourse of Athens and the democratic ideology. ${ }^{31}$ Admitting the fragile basis of the argumentation of Hellanicus as favorable to Athens, Baurain-Rebillard finds an explanation by paying attention to the little information we have about the life of Hellanicus and contrasting that (and the fragments) with the events of Hellanicus' time.

Concernant Thésée, Hellanicos pourrait avoir dépoillé des sources peu favorables à Athènes, à une époque où la tension montait entre elle et Sparte. On se rappellera aussi qu'Hellanicos était originaire de Mytilène, qui, après sa révolte de 428-7, a subi

29. Idem, 28-30.

30. Baurain-Rebillard, “Thésée, le rapt d'Hélène et Hellanicos: les origines politiques d'une réprobation morale," in Héros Grecs à Travers le Temps: Autour de Persée, Thésée, Cadmos, et Bellérophon (Metz: Centre de Recherches Universitaires Lorrain d'Histoire, 2016), 224-225. I reinforce here that the fragments 168a and 168b come from Plut. Thes. 31 and from Tz. ad. Lyc. 1332. So the information that Helen was seven years old came to us solely from a byzantine author of the 12th century. Regardless, Plutarch had already a sense of moral reproach in the text of Hellanicus, which makes it acceptable to think that John Tzetzes is trustworthy.

31. Walker, Theseus and Athens (Oxford: Oxford University Press, 1995), 35, 52-53, 6466; Claude Calame, Thésée et l'imaginaire athénien: légende et culte en Grèce antique (Lausanne:

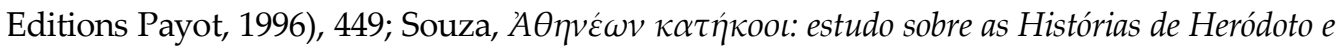
sua crítica ao Império Ateniense, 2020, 70-72. It is useful to remember that "o Teseu de Heródoto aparece nessa única ocorrência manchado pelo rapto de Helena, ao que Heródoto nomeia como üßoıs [...]. O Teseu de Heródoto é insolente, um arrogante, um destemperado; é um úß@ıт七ńs" I "the Theseus of Herodotus appears in this sole occurrence spotted by the kidnap of Helen, to what Herodotus calls v́ßoıৎ [...]. The Theseus of Herodotus is insolent, arrogant, and

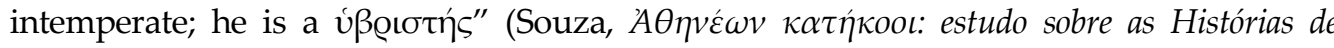
Heródoto e sua crítica ao Império Ateniense, 2020, 89-90). Therefore, Hellanicus could be the source of Herodotus and vice versa, but it is relevant to note that these two metics decided to use the same version; that one different from the Athenian. 
une répression féroce de la part d'Athènes, n'échappant que de peu à la destruction totale. Avant même cette date, des critiques s'étaient forcément élevées, à Mytilène et, au-delà de l'île de Lesbos, dans bien d'autres Cités de la Ligue de Délos. Critiquer Thésée, rabaisser son prestige, cela pouvait être une façon d'exprimer son mécontentement à l'égard d'une Athènes qui outrepassait ses prérogatives de Cité hégémonique. ${ }^{32}$

She explored how the paintings on Athenian ceramic show a different image of Theseus, without the tremendous difference between him and Helen. The Athenian discourse, of course, was using the figure of Theseus in the same way as its cultural figures at Delphi, for example, to legitimize their position through the Pan-Hellenic discourse. ${ }^{33}$ But Hellanicus' discourse was constituted in a different way, and this is as much relevant information as he running from the Athenian discourse about Harmodius and Aristogeiton, as Fornara pointed out.

Ce qui est clair en revanche, c'est que les peintres d'Athènes montrent l'enlèvement sans connotation nègative, bien plutôt comme une preuve supplémentaire de la vigueur du héros national, et en tout cas jamais avec la différence d'âge qui ferait de Thésée un pervers pédophile. En introduisant des considérations d'âge totalement étrangères à la pensée mythique - qui n'avait que faire du temps mesurable des hommes et de la rationalité - , Hellanicos, passionné de chronographie et animé d'une volonté d'organisation logique des légendes diverses des Cités grecques (et sans doute aussi d'une certaine rancune à l'égard d'Athènes), a terni l'image de Thésée. Le rapt $\mathrm{d}^{\prime}$ Hélène a d'abord servi le dénigrement d'Athènes et/ou de la démocratie. ${ }^{34}$

32. Baurain-Rebillard, “Thésée, le rapt d'Hélène et Hellanicos: les origines politiques d'une réprobation morale," 2016, 225. "Related to Theseus, Hellanicus could have looked for sources unfavorable to Athens, in a time when the tension between it and Sparta was growing. Let's also remember that Hellanicus was originally from Mytilene, which, after her 428/7 rebellion, fell under ferocious repression by Athens, barely escaping from total destruction. Even before that, the critics must have been numerous in Mytilene and, beyond the island of Lesbos, in many other cities of the Delian League. To criticize Theseus, to reduce his prestige, could be a way of expressing their dissatisfaction with an Athens that surpassed its prerogatives of a hegemonic city."

33. Krikona, "The Notion of Panhellenism through Athenian and Syracusan Dedications in Apollo's sanctuary at Delphi in the early $5^{\text {th }}$ century BCE," in Through the Eyes of a Stranger: Appropriating Foreign Material Culture and Transforming the Local Context, edited by Ana Popović (Zagreb, 2018), 51.

34. Ibidem, 231. "What is clear, on the other hand, is that the painters of Athens show the kidnap without negative connotation, but as additional evidence of the national hero's strength and, in any case, never with the age difference that would make Theseus a wicked pedophile. Introducing considerations of age totally strange to the mythic thinking - that was related just to the measurable time of men and to rationality - Hellanicus, passionate to chronography and driven by a desire for logical organization of the various legends of the Greek Cities (and with no doubt with some bitterness toward Athens), 
Maybe we could be more careful when we speak of democracy critics, but it is relevant to notice that 'democracy', or at least a popular government, means 'Athens' in a context where Athens sometimes imposes democracy over the rebels of the Delian League, like it was done with Samos. In any case, the propositions of Baurain-Rebillard touch a very important detail: the birthplace of Hellanicus. If we pay more attention to the situation of the Delian League, it's possible to recognize a strong domain that was controlled by Mytilene before the rebellion and its suppression by Athens. As Sean Jensen demonstrated, inside the Delian League and the Athenian Empire there were some sub-hegemonies across the Aegean Sea, and Mytilene was one of them.

\section{Mytilene in Geopolitics and Hellanicus' Real Place in Athenian Empire}

Retracing the known facts, Mytilene seems to have controlled the same places across the Troad since the Archaic Period, and although we have less evidence about the size of that sub-hegemony, we know that around $425 \mathrm{BC}$ Mytilene received tribute from thirteen poleis. ${ }^{35}$ We also know that Athens didn't intervene in this political situation of Troad, but when the Mytilenians tried to constitute a synoecism with its neighbors, and later with the interference of Athens, there was a revolt ${ }^{36}$. After the revolt, Athens executed the leaders, demolished the wall of Mytilene, confiscated the fleet, and distributed three thousands of land plots for Athenians as clerurchies. ${ }^{37}$ Moreover, the Athenians took the sub-hegemony of Mytilene and didn't restore it for them even after the devolution of the autonomy of the Lesbian polis. ${ }^{38}$ It maintained anti-Athens Mytilenians resisting to the Athenian politics and acting for revolt in those peripheries of the old Mytilenian sub-hegemony. ${ }^{39}$ And there was even a revolt in $412 \mathrm{BC}$.

Few works used this sequence of events as a parameter to understand Hellanicus' text. As it has happened to Herodotus, who firstly was seen as a partisan of Athens. However, differently from Herodotus, the text of Hellanicus didn't reach us in an expressive volume of information. As a result, the many studies that examined the Histories and described the allusions to Herodotus' present time and the context of the Peloponnesian War and the Athenian Empire are completely impossible in Hellanicus' case. We can speculate, imagine, suggest,

smears the image of Theseus. The kidnapping of Helen served, first of all, to denigrate Athens and/or the democracy."

35. Jensen, Rethinking Athenian Empire: Sub-Hegemony in the Delian League, Doctoral Thesis (New Burnswick: The State University of New Jersey, 2010), 194-196.

36. Idem, 197-199.

37. Idem, ibidem.

38. Idem, 202.

39. Idem, 203-204. 
even find some evidence, but anything we could find wouldn't be enough to determine if Hellanicus was criticizing Athens or not. What we have as evidence are limited points. It is clear that Hellanicus was writing about some Attic traditions in a different way from how the Athenians narrate them. We have the example pointed out by Baurain-Rebillard and we have another one made by Fornara. Those two examples show us a similarity between Hellanicus and Herodotus: both disseminated different versions from what Athenians proclaimed. The case of Herodotus is about the origins of the Athenians. Indeed, Herodotus rejects the discourse of autochthony and considers the Athenians descendants from the Pelasgians ${ }^{40}$. Susan Lape argued that such a different version was a way to confront directly the discursive pretensions of the Athenians to legitimize its power and solidity ${ }^{41}$. I suggest that the same logic can be applied to Hellanicus, but we don't have more evidence to reinforce this point as we do in Herodotus. For in Herodotus' work there are innumerous other examples of a critical stance toward the Athenian Empire, expressed across the nine books of Histories, that we can read profusely. ${ }^{42}$

Hellanicus didn't seem to disagree with the tradition that talked about the autochthony ${ }^{43}$. He seems to speak of the success of the Athenians in the past, ${ }^{44}$ but it doesn't mean that he has defended his contemporary Athens: Herodotus praises the Athenians of the past, without saving Themistocles from critics, and it just means in his Histories that the Athenians of the present fell in a tragic sequence of hybris that culminates in the destruction of its empire. ${ }^{45}$ But one of the most significant fragments is the one in which Hellanicus claims an ironic ancestry for Andocides. ${ }^{46}$ We have no sufficient information to trace the limits of Hellanicus' life, but it's still possible that he lived until 407 BC. Even if it was just until $411 \mathrm{BC}$, there is a possibility that his Atthis was published after the events of $415 \mathrm{BC}$. And if it is right, to write about a strong relation between Andocides and Hermes means that the text of Hellanicus dialogues more with its own time than to anything. For the simple fact that, in $415 \mathrm{BC}$, the mutilation of the Herms was a scandal in Athens, near the expedition to Sicily, and Andocides was one of the

40. Hdt. $1.56 ; 7.95 ; 8.44$.

41. Lape, Race and Citizen Identity in the Classical Athenian Democracy (Cambridge: Cambridge University Press, 2010), 149-155.

42. As, for example, the work of Rosaria Munson (1988), that suggested that the acts of Artemisia in the Histories are an allusion to Athens and its politics; or the work of Blösel (2001; 2004) that suggests the same for Themistocles. Or even the work of Raaflaub (2002) that establishes relations between the Persians and the Athenians. These are just three examples of many other works in this way.

43. FGrH 4 F 47.

44. FGrH 4 F 47a-47b.

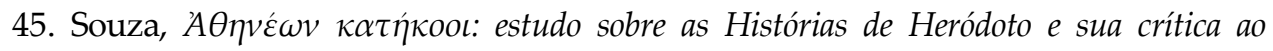
Império Ateniense, 2020, 149-150, 154-155, 195-196.

46. FGrH 4 F 170. 
many accused of committing that crime, posteriorly accusing others and creating an alibi ${ }^{47}$. I would like to remark that this information opens different possibilities of interpretation and that nothing is conclusive. Nevertheless, we can infer that Hellanicus was trying to defend Andocides. Or we could think that Hellanicus was criticizing the spirit of terror established in Athens. We can also surmise that Hellanicus was suggesting that Athenians have no loyalty even with their nearest gods.

Unfortunately, without considerable material from the text of Hellanicus, all of it is just speculation. However, I suggest that every reading of the fragments of Hellanicus must consider first that he probably would have a more distant and critical view of Athens. Not just because of the cultural differences (and here I remember the discussion about differentiating or not what is ethnography and horography), but because of the political and economic events described above. It is not very likely that Hellanicus would write a text completely sympathetic to Athens. Even less neutral. What is more acceptable is that he wrote a text that permitted a critical view without the risks of a direct political alignment clearly engraved in his words, as Herodotus did as well. Maybe it was a common tendency in historiographical texts of that time and foreigner to Athens, such as Ion of Chios, Stesimbrotos of Thasos, Idomeneus of Lampsacus, although tradition considered these examples as naturally critical. ${ }^{48}$ I defend that Hellanicus must be framed as one of them.

The last fragment I would like to discuss is the one Hellanicus probably wrote about the gold coinage of Athens under the archonship of Antigenes, between $407 / 6$ BC..$^{49}$ It is interesting to contrast this possible writing with the information that Mytilene used to produce a gold-silver alloy coinage (electrum), since 520s/510s BC and had a probable interruption exactly in the period when Athens took its peraia and disarticulated the sub-hegemony (427-405), until the defeat of the Attic polis. ${ }^{50}$ This coinage returned and stayed until the 330s/320s. Near 427 BC, soon to the revolt against Athens, the Mytilenians were already producing silver coins instead of electrum, and with less weight of the Athenian coins. ${ }^{51}$ Maybe Hellanicus was just pointing out a fact about Athens. But maybe Hellanicus lived long enough to see the defeat of Athens and was trying to create a hybristes image of it: not much time after coining with gold, after taking it from Mytilene, Athenian hegemony fell. Well, it seems an exaggerated image, but considerations of this kind have been made all the time on authors such as Herodotus when we have more material to analyze. And the fact we don't know precisely the date when Mytilene interrupted its electrum coinage (and if it was a

47. Canfora, O Mundo de Atenas (São Paulo: Companhia das Letras, 2015), 234-261.

48. Idem, 134. Referred tradition is essentially Plutarch, as pointed out by Canfora.

49. FGrH 4 F 172.

50. Ellis-Evans, The Kingdom of Priam: Lesbos and the Troad between Anatolia and the Aegean (Oxford: Oxford University Press, 2019), 189-190.

51. Idem, 190-191. 
direct consequence of the repression of Athens) is less important. Hellanicus maybe didn't know the exact date. Or maybe didn't care, hoping that his audience/readers didn't care either. It could be a simple and intentionally imprecise allusion. Again, we have no sufficient material to check speculations like these.

\section{Conclusion}

In resume, we don't have enough amount of writings to infer political alignment and critical stance with precision. However, we are not able to imagine a neutral Hellanicus just trying to achieve fame and glory through his texts and completely apart from any political position. Surely, the revolt of Mytilene and its consequences, the disarticulation of the sub-hegemony of that polis must influence the composition of Hellanicus's Atthis, especially because it is reasonable to think that Hellanicus was preparing his work during the Peloponnesian War (having started before it) and that its publication came at the end of the war. ${ }^{52}$ By the way, Hellanicus probably had more chances to be a critic of Athens than Herodotus himself, because the later wasn't from a mighty center of sub-hegemony that had been disarticulated by the revenge of Athens. And even so, Herodotus was a visceral but subtle critic of Athens. To believe that Hellanicus had only literary aspirations is naïve and, despite the little information and the impossibility of deeply exploring the political alignment of the author, I suggest that we should always maintain the political implications of the text highlighted. Even if we cannot be sure about the content of those texts, paying attention solely to literary questions may lead us to the risk of erasing part of the author's materiality and limit precise considerations about the author's ethos and the relations between the historiographical texts and politics, economy and culture.

\section{Bibliography}

Aloni, Antonio. Tradizioni arcaiche della Troade e composizione dell'iliade. (Archaic tradition of the Troad and composition of the Iliad.) Milan, 1986.

Ambaglio, Dino. "L'opera storiografica di Ellanico di Lesbo" (The Hellanicus of Lesbos' historiographic opera.) Ricerche de Storiografia Antica 2 (1980).

"Ellanico, un Lokalpatriotismus problematico" (Hellanicus, a problematic Lokalpatriotismus.) In Eoli ed Eolide tra Madrepatria e Colonie, 135-144. Naples: Luciano Editore, 2005.

Baurain-Rebillard, Laurence. “Thésée, le rapt d'Hélène et Hellanicos: les origines politiques d'une réprobation morale." (Theseus, the kidnapping of Helen and Hellanicus: the political origins of a moral reprobation.) In Héros Grecs à Travers le Temps: Autour de

52. Polychronis, Hellanicos de Lesbos: Histoire des origines, origines de l'Histoire, 2018, 78. 
Persée, Thésée, Cadmos, et Bellérophon, 213-232. Metz: Centre de Recherches Universitaires Lorrain d'Histoire, 2016.

Biraschi, Anna M. Tradizioni epiche e storiografia: Studi su Erodoto e Tucidide (Epic tradition and historiography: studies on Herodotus and Thucydides.) Naples: Edizioni Scientifiche Italiane, 1989.

Blösel, Wolfgang. "The Herodotean Picture of Themistocles: A Mirror of Fifth-Century Athens." In The Historian's Craft in the Age of Herodotus, 179-197. Oxford: Oxford University Press, 2001.

. Themistokles bei Herodot: Spiegel Athens im füften Jahrnhundert: Studien zur Geschichte und historiographischen Konstruktion des griechischen Freiheitskampfes 480 v. Chr (Themistocles in Herodotus: Athens mirror in the Fifteenth Century: Study on History and historiographic construction of the 480 BC Greek fight for freedom.) Stuttgart: Franz Steiner Verlag, 2004.

Brunt, P. A. "On Historical Fragments and Epitomes." The Classical Quarterly 30, no. 2 (1980): 477-494.

Calame, Claude. Thésée et l'imaginaire athénien: légende et culte en Grèce antique. (Theseus and the Athenian imaginary: legend and cult in Ancient Greece.) Lausanne: Editions Payot, 1996.

Canfora, Luciano. O Mundo de Atenas (The Athens World.) São Paulo: Companhia das Letras, 2015.

Ellis-Evans, Aneurin. The Kingdom of Priam: Lesbos and the Troad between Anatolia and the Aegean. Oxford: Oxford University Press, 2019.

Fornara, Charles W. "Hellanicus and an Alcmaeonid Tradition." Historia: Zeitschrift für Alte Geschichte 17, no. 3 (1968): 381-383.

Harmatta, János. "La tendance politique d'Hellanicos dans les Troikà" (The political tendency of Hellanicus in the Troika.) In Actes IX Congrès Association G. Budé. Paris, 1975, 147-150.

Irwin, Elizabeth. "The Politics of Precedence: first "historians" on first "thalassocrats"." In Debating the Athenian Cultural Revolution: Art, Literature, Philosophy, and Politics 430380 B.C., 188-223. Cambridge: Cambridge University Press, 2007.

. "Herodotus and Samos: Personal or Political?" The Classical World 102, no. 4 (2009): 395-416.

. "The End of the Histories and the End of the Atheno-Peloponnesian Wars." In Interpreting Herodotus, 279-334. Oxford: Oxford University Press, 2018.

Jensen, Sean Ryan. Rethinking Athenian Empire: Sub-Hegemony in the Delian League. Doctoral Thesis. New Burnswick: The State University of New Jersey, 2010.

Joyce, Christopher. "Was Hellanikos the first chronicler of Athens?" Histos 3, no. 1 (1999): 117.

Krikona, Eleni. "The Notion of Panhellenism through Athenian and Syracusan Dedications in Apollo's sanctuary at Delphi in the early $5^{\text {th }}$ century BCE." In Through the Eyes of a Stranger: Appropriating Foreign Material Culture and Transforming the Local Context, edited by Ana Popović. Zagreb, 2018, 38-57.

Lape, Susan. Race and Citizen Identity in the Classical Athenian Democracy. Cambridge: Cambridge University Press, 2010.

Marques, Juliana Bastos. "Historicizando as categorias de Felix Jacoby: os gêneros historiográficos da Antiguidade e sua classificação pelos modernos" (Historicizing 
Feliz Jacoby's categories: the Antiquity's historiographic genres and their classification by the moderns.) In Fronteiras Mediterrânicas, 225-250. Porto Alegre: Editora Fi, 2019.

Munson, Rosaria. “Artemisia in Herodotus." Classical Antiquity 7, no. 1 (1988): 91-106.

. "Herodotus and the Heroic Age: the case of Minos." In Myth, Truth, and Narrative in Herodotus, 195-212. Oxford: Oxford University Press, 2012.

Payen, Pascal. "A constituição da história como ciência no século XIX e seus modelos antigos: fim de uma ilusão ou futuro de uma herança?" (The constitution of History as science in the nineteenth century and its ancient models: ending of an illusion or the future of a heritage?) História da Historiografia, no. 6 (2011): 103-122.

Perrin, B. "The Iereiai of Hellanicus and the Burning of the Argive Heraeum." The American Journal of Philology 22, no. 1 (1901): 39-43.

Polychronis, Théodossios. Hellanicos de Lesbos: Histoire des origines, origines de l'Histoire (Hellanicus of Lesbos: history of the origins, origins of the History.) Doctoral Thesis. Paris: Université d'Aix-Marseille - Faculté des Lettres, 2018.

Raaflaub, Kurt. "Philosophy, science, politics: Herodotus and the intellectual trends of his time." In Brill's Companion to Herodotus. Leiden: Brill, 2002.

Rood, Tim, Carol Atack and Tom Phillips. Anachronism and Antiquity. London: Bloomsbury Academic, 2020.

Sammartano, Roberto. Origines Gentium Siciliae: Ellanico, Antioco, Tucidide (Origins of the Scilinian people: Hellanicus, Antiochus, Thucydides.) Roma: Gustavo Bretschneider, 1998.

Skinner, Joseph E. "Writing Culture: historiography, hybridity, and the shaping of collective memory." In Histos Supplement 11 - Shaping Memory in Ancient Greece: Poetry, Historiography, and Epigraphy, 189-234. 2020.

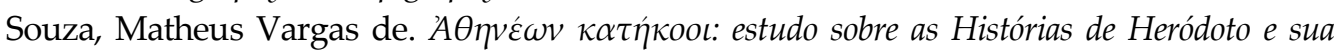
critica ao Império Ateniense (Athens subjects: study on Herodotus' Histories and his critic to the Athenian Empire.) Masters Dissertation. Rio de Janeiro: Programa de PósGraduação em História - Universidade Federal do Estado do Rio de Janeiro, 2020.

Vanotti, Gabriella. "Egesta ed Esione da Ellanico di Lesbo a Dionisio di Alicarnasso" (Egesta and Esione from Hellanicus of Lesbos to Dionysius of Halicarnassus.) In Tra panellenismo e tradizioni locali: Nuovi contribute, 317-348. Messina: Dipartimento di Scienze dell'Antichità, 2011.

Walker, Henry J. Theseus and Athens. Oxford: Oxford University Press, 1995. 
